University of Warwick institutional repository

This paper is made available online in accordance with

publisher policies. Please scroll down to view the document

itself. Please refer to the repository record for this item and our

policy information available from the repository home page for

further information.

To see the final version of this paper please visit the publisher's website. Access to the published version may require a subscription.

Author(s): Matthew Watson

Article Title: Gordon Brown's Misplaced Smithian Appeal: The Eclipse of Sympathy in Changing British Welfare Norms

Year of publication: 2009

Link to published version:

http://dx.doi.org/10.1017/S0047279408002808

Publisher statement: None 


\title{
GORDON BROWN'S MISPLACED SMITHIAN APPEAL: THE ECLIPSE OF SYMPATHY IN CHANGING BRITISH WELFARE NORMS
}

\author{
MATTHEW WATSON, UNIVERSITY OF WARWICK, UK
}

PUBLISHED IN THE JOURNAL OF SOCIAL POLICY, 38 (2), 2009, 195-210

\begin{abstract}
Gordon Brown has eagerly lauded his fellow Kirkcaldy citizen, Adam Smith, as his main policy inspiration. This article tests the rigour of such a claim by matching Brown's promotion of Smithian 'sympathy' as the centrepiece of his programme for government with the changes introduced by his Treasury to the British welfare model. In the 1970s, Thomas Wilson showed that the traditions of the post-war British welfare state were compatible with a modified form of Smithian sympathy socialised at the level of the state. New Labour has set about reforming the welfare model with respect to both its underlying institutions and the basic subjectivities of its recipients. I show that Brown's substantive preference for an asset-based system of welfare moves those subjectivities away from the 'relational self' of Smithian sympathy and towards a much more 'autonomous self'. Consequently, I conclude that it is stretching Smith's concept of sympathy too far, even in a modified socialised form, to associate it with New Labour’s asset-based system of welfare.
\end{abstract}

\section{KEY WORDS}

Gordon Brown; Adam Smith; sympathy; relational self; post-war British welfare state; autonomous self; asset-based system of welfare 


\section{INTRODUCTION}

From the beginning of New Labour's second term in 2001 onwards, Gordon Brown has argued that the main influence on his economic thinking is a man born in the same Fifeshire town as him, Adam Smith (Lee, 2007, 41-65). The root of such a claim rests in Brown's frequently voiced desire that Labour learns once again how to 'show its soul': to demonstrate that it sympathises with and shares the aspirations of those people who might otherwise feel left behind by its stated public priority of enhancing national economic competitiveness (Brown, 2005b, 2006b, 2007). Sympathy, of course, was the core concept underpinning Smith's Theory of Moral Sentiments. However, I will use this article to argue that the seemingly close relationship between the two sons of Kirkcaldy is not what it initially seems, at least not in the sphere of reconstituting the model welfare citizen.

Smith suggested that sympathy is a self-tutored manifestation of the individual's moral faculties, through which he or she learns how to enact moral judgement appropriate to the needs of societal living. In this, he was clear that the process of self-tutoring is entirely internal to the individual and requires no external influence other than the recognition that individual life must always be lived within society. Yet, Brown's appeal to the same concept invokes relationships which are either mediated or coerced by the state. Even the communitarian instincts of the recent Department of Communities and Local Government White Paper (DCLG, 2008) which endorses a strong desire for fostering sympathy within local neighbourhoods envisions the establishment of community links via facilitative state activities. Viewed from a Smithian perspective, then, the result is that Brown has attempted to socialise sympathy through the agency of the state, which seems directly contrary to 
Smith's suspicions of the interventions of a well-meaning government (Smith, 1981 [1776], V.ii.h.12). Smith's sympathy is all about the individual honing his or her moral instincts, but Brown's socialised sympathy sidesteps the sphere of individual moral development altogether, in favour of policies which incentivise certain forms of behaviour simply as a rational response to state interventions in everyday life. In this sense, they are merely a subset of the general orientation towards rational actor models which appear to dominate current policy thinking.

I show that all manifestations of socialised sympathy are not necessarily incompatible with the instincts of genuine Smithian sympathy. Certainly, it is possible to reconstruct the institutions of the post-war British welfare state in such a way. My argument is restricted to the possibility that New Labour's reforms to the welfare state - in particular its attempts to negotiate the move towards an asset-based system of welfare - negate the socialised sympathy associated with post-war welfare citizens.

In order to draw out the contrasts that lay at the heart of my argument, the article proceeds in three stages. In section one, I outline Smith’s concept of sympathy in order to provide a point of reference for the remainder of the analysis. I focus in particular on the way in which sympathetic relationships facilitate the development of 'relational selves' who balances the needs of others with their own (Weinstein, 2006). In section two, I create a further comparator against which to review Brown's appeal to the legacy of socialised Smithian sympathy. This is achieved through a study of existing academic attempts to apply the basic concept to the institutions of the postwar British welfare state. The deliberate development of an accompanying legitimacy structure for the welfare state does indeed appear to be consistent with something akin to socialised Smithian sympathy. In section three, I show that the Treasury's recent attempts to reconstitute the model welfare recipient change in important ways the 
operation of those institutions and their legitimacy structure. The new model welfare citizen in the political economy of New Labour appears best able to thrive when stripped of all pretence to genuine Smithian sympathy in the interests of performing duties to the self and to the state.

\section{SMITHIAN SYMPATHY VERSUS THE INSTITUTION OF DUTIFUL BEHAVIOUR}

Adam Smith's Theory of Moral Sentiments emphasises the significance of sympathy so that social life can flourish beyond the perfunctory enactment of duties. To have individuals behaving dutifully in accordance with the principles of justice is what makes life within society possible in the first place (Smith, 1982 [1759], II.ii.3.4). Yet, on its own it does not necessarily make it more than tolerable. The instinctive incorporation of sympathetic dispositions transcends merely tolerable existence and turns it into a worthwhile human experience (ibid, II.ii.1.8). A world shaped in the image of sympathy is therefore his preferred alternative to a world regulated solely by duty.

To get to the bottom of the difference between sympathy and duty, it is first necessary to understand the significance that Smith attached to what lies between the intrinsically fallible individuals of everyday life and the ideal individual of abstract philosophy. He envisaged an intermediary between what people are actually like in untutored circumstances and what they could be given suitably moral tutelage. He ascribed to that intermediary a role in guiding action akin to conscience. He called it the 'impartial spectator', and it allows individuals to begin to transcend their innate fallibilities. It exists as a mechanism for moving beyond Smith's second-best moral 
realm of dutiful behaviour and into the first-best moral realm of sympathetic behaviour.

The impartial spectator is a product of the individual's imagination (Smith, 1982 [1759], III.1.5) and is activated whenever well-honed moral faculties sense that a moral judgement is required (ibid, III.1.2). Significantly, it takes the form of a person, although it clearly only has a psychological rather than a physical presence, and it exists within the self to make particular behavioural patterns more likely than others. In perhaps the most evocative description, Smith referred to it as 'the inhabitant of the breast, the man within, the great judge and arbiter of our conduct' (ibid, III.3.4). The impartial spectator is the imaginatively projected imprint of an autonomous being through whose eyes we can visualise the effects of being placed in certain circumstances and of how to come to a decision about the appropriate way to act in those circumstances.

It is through the activation of the impartial spectator that an individual learns the conduct of a sympathetic being (ibid, I.i.5.8, I.ii.4.1). The key to a sympathetic relationship in Smithian terms is when the emotions of the impartial spectator are in accord with those of the person directly implicated in an event, thus producing a genuine instance of fellow-feeling. In emphasising this aspect of the concept, Smith's use of the word 'sympathy' takes us back to its original Greek etymology (see Montes, 2004, 8). The Greek word 'sumpátheia' derives from sun- (meaning 'with’) and pathos (meaning 'feeling'). To sympathise with someone from this perspective means literally to feel with them: to share in their feelings by assimilating them vicariously.

The individual learns how to engage in sympathetic relationships by mixing observation with imagination. According to Smith, people only sense that moral 
judgements are required by observing events unfold which necessitate that they provide an emotive response to symbolise the fact of being fellow members of society. Such observations can take place either directly, as a result of the evidence of one's own eyes, or indirectly, as a result of hearing a second-hand account. The observation then has to be internalised if it is to call forth the type of emotive response which lies at the heart of moral judgement.

The route to that judgement, according to Smith, passes through seeing other people interact with their surroundings and reinterpreting the observation as if those surroundings were suddenly transplanted to become a part of the observer's own experience. As he noted, sympathy 'does not arise so much from the view of the passion, as from that of the situation which excites it' (Smith, 1982 [1759], I.i.1.10). We have to attempt to temporarily swap sensations with the person most immediately affected by an event if we are to develop a feel for its wider social connotations. We do this through psychic projection, enforcing a direct replica of the situation just observed into our own mind so as to enquire of our sensate capacities what our emotive response would have been had we been the person directly confronted by the event and not merely the observer of it. The impartial spectator is actualised in order to imprint on the imagination our most likely sensory response to the situation that the other person has so recently experienced. If the imprint left by the impartial spectator matches the observation of the other person's response then the two emotive selves are in concord. An occurrence of genuine fellow-feeling has ensued and, from Smith's perspective, this equates to an equally genuine sympathetic relationship (ibid, I.i.2.6).

The constant interaction which every person has with other members of society serves as a means of moral self-tutelage (Griswold, 1999, 128-9). As soon as we learn to employ the imaginative faculties to judge the propriety of other people's 
emotive responses, we can change the focus of the response from situations actually created by a third party to situations which would be created were we to pursue a particular course of action. This involves a substantively more complex psychic projection, but the basic principle of imaginatively reconstructing a vicarious response is the same as before.

In this instance, the aim is to obtain an imprint in the imagination of the most likely response of another person to our own intended conduct. We can not only judge other people through our own senses; we can also judge ourselves through using those same sensate capacities to understand how our behaviour affects the conditions of other people's lives. If the impartial spectator tells us from our own perspective that another person's most likely response to our intended conduct is justifiably condemnatory, then we are warned against embarking on such a course of action. It is only when other people's most likely response to our intended conduct is justifiably affirmatory that we will feel sufficiently confident in undertaking the conduct. The ability to discriminate increasingly instinctively between when to proceed and when not forms the basis of the learned art of moral judgement.

Genuine processes of Smithian sympathy are therefore constructed inextricably within an interpersonal realm in which the mind is constantly suffused with repeated images of both 'self' and 'other' (Boltanski, 1999, 40-1). This alters both the nature of basic cognition and, in time, the very representation of the self. Jack Russell Weinstein $(2006,4)$ suggests that Smith's whole approach to the question of moral judgement is grounded in the assumption of 'what is now termed a relational self'.

It is now possible to return to the distinction outlined at the beginning of this section, through which Smith insisted that there were important practical differences 
between living in a social state regulated by sympathy and in one regulated by duty. The most significant difference relates to the type of person whose presence is implied by the two. In a world regulated by duty, the individual does not need to develop a relational self via the constant interplay in the imagination of the imprints of 'self' and 'other'. To act solely out of duty requires the individual to internalise nothing more than a technical understanding of norms of justice laid down by the broader body of law (Smith, 1982, 431-3). A perfectly autonomous self is suited to such a task, whereby all interpersonal relationships are mediated by legal statutes. This is a very different world from one in which a relational self flourishes to guide the contact between one person and another. It is only in these latter circumstances that genuine Smithian sympathy arises.

The distinction between duty and sympathy is as central to the analysis which follows as it was to Smith. Applying basic Smithian units of analysis, the substantive changes associated with New Labour's remaking of the British model of welfare represent a decisive break. The post-war welfare state derived its legitimacy from what appears to be the equivalent - albeit in modified form - of Smithian sympathy. By contrast, Treasury-inspired reforms under Gordon Brown's stewardship have moved Britain closer to an asset-based system of welfare which derives its legitimacy from a particular construction of Smithian duty. The two are not the same, as they infer pretty much systematic remodelling of the individual with respect to everyday economic life. The reproduction of the post-war welfare state assumed the existence of relational selves throughout society, whereas the contemporary system of assetbased welfare assumes autonomous selves. This does not necessarily make the policy misguided, but the Treasury's attempted transformation of the subjectivities of welfare recipients in Britain is not consistent with genuine Smithian sympathy. Before 
heading towards the conclusion, however, it is first necessary to add substance to claims about the changing British model of welfare.

\section{THE POST-WAR BRITISH WELFARE STATE AND THE SOCIALISATION OF SMITHIAN SYMPATHY}

Gordon Brown's stated mission as Chancellor of the Exchequer was to target 'the relentless pursuit of stronger markets' (Brown, 2003a, 284). He also sees it as the task of government to ask how the introduction of markets might change both the delivery of public services and the mindset of those who are affected by their delivery (Brown, 2006a, 2007). Yet, beneath such pronouncements there lies an appreciation of the fact that market failure is a possibility (Brown, 2003b). Iain McLean believes that it is his views on market failure that show Brown most clearly to be working within a Smithian legacy, describing that position as ‘a pure distillation from Adam Smith's views’ (McLean, 2006, 91).

The instituting of the post-war British welfare state represents what is almost certainly the grandest systematic attempt in the country's political history to cope with the manifestations of market failure. It is always important to remember that there are, in Gøsta Esping-Andersen’s well-used phrase (1990), distinct ‘worlds of welfare’, and that Britain remained resolutely 'not Sweden' in the depth of incorporation of welfare entitlements into the prevailing social formation. The debate about worlds of welfare often revolves around the comparison of ideal-types, and a brief note of caution should be issued because my analysis of shifting welfare state norms is no different in that respect. Nonetheless, the achievements of the post-war British welfare state should not be belittled, whether we conceive of it in purely heuristic terms or not. 
Universal healthcare was established, free at the point of need, and the system of national insurance contributions was significantly expanded. This allowed for the payment, amongst other things, of a state pension and a family allowance. All of these were examples of social insurance to correct the market failure in private provision which left so many people uninsured.

There is a relatively straightforward link which can be made between Smith's account of moral judgement and the introduction of the post-war British welfare state. The expansion of social rights can be reconstructed as evidence of what happens when acts of the imagination allow the standpoint of the materially disadvantaged to force its way onto the legislative agenda. The greater the number of parliamentary representatives drawn directly from constituencies representing the needy, the more chance there was that legislation of this nature would be passed. The increased debating time spent in discussions provided a means of imprinting potential welfare recipients' lives on the imaginations of MPs. This in turn prompted them to effect the moral judgement which led to acceptance of increasingly robust systems of social insurance.

However, this only links Smithian sympathy to the process of bringing about changes in the law in order to counteract instances of market failure. It says nothing about the substantive structures of the welfare state, nor yet about the model welfare state citizen on which the legitimacy of the structures depended. Does the link to Smithian sympathy still hold at these levels?

To my knowledge, such a question has been tackled only once in any systematic way in the existing literature. That was by Thomas Wilson, in an analysis written in 1976 as part of the bicentennial commemoration of the first publication of Smith's Wealth of Nations. At that time he held the Adam Smith Chair in Political 
Economy at the University of Glasgow. Wilson's overall thesis was that two outcomes were necessary if modern circumstances were to be characteristic of Smith's eighteenth-century liberalism. (1) The state will forfeit its legitimacy if it is understood to be encroaching on the territory of individual liberty solely for its own self-aggrandisement. (2) The state will be unable to generate sufficient affection from its citizens unless it introduces compensating systems of redistribution designed to assist the most disadvantaged within society (Wilson, 1976, 94).

Wilson argued that the post-war British welfare state met both of these conditions. It certainly encroached on the autonomy of the individual by forcibly incorporating the whole of society into a fiscal system designed to ensure the reproduction of welfare entitlements. Yet, this was not the expansion of the state for its own sake. The prevailing model of welfare served as a crucial factor of cohesion in the social formation, facilitating a period of structural economic change in the absence of a wholesale popular backlash against the accompanying social upheavals. The redistributive logic of its fiscal system was the means of social management. Whilst the middle classes were by no means penalised by the post-war welfare state, politicians were nonetheless able to point to the poor as obvious beneficiaries from its operation. Smith, it should be noted in passing, argued that each individual had a special responsibility to the poor merely on the basis of the latter's material conditions of existence (Smith, 1982 [1759], VI.ii.1.2). He also suggested that external influence in the form of legal statutes could reasonably be called on to enforce those responsibilities if people were reticent in acting on them voluntarily (ibid, II.ii.1.5).

Wilson's account of the basic essence of the post-war British welfare state therefore appears to have many fundamental Smithian features. But it is another matter whether these features map decisively onto Smith’s core concept of sympathy. 
At most here we are talking about a modified, socialised form of sympathy. Smith described its operation solely in terms of the relationship between one person and another (ibid, I.i.1.4). Yet, the whole ethos of the welfare state is that it intervenes in such relationships, potentially masking the most important attribute which Smith attached to genuine sympathy.

Lying behind Wilson’s argument is an appreciation that markets have changed since Smith's day as an arena of social engagement (see Braudel, 1982). At the beginning of the commercial age, markets were physical meeting places which involved interaction of a face-to-face nature. This type of market experience consequently influenced the notion of sympathy that Smith constructed in order to explain how moral limits are imposed on specifically economic behaviour. It conditioned all market-based interactions with a genuinely interpersonal character: sympathy constitutes the process through which two people make a market exchange when they share a single social space. However, this was not the nature of most exchange relations by the time that Wilson was writing (Slater and Tonkiss, 2001). Increasingly over the last two hundred and fifty years, the direct interpersonal character of the relationship between producer and consumer has diminished. This raises the question of whether the sympathy that regulated market behaviour for Smith must also have evolved along similar lines in the context of clear market failure.

Wilson's argument was that it has. Given the anonymity of so many exchange relations today, it is unlikely that the demand for exercising sympathetic capacities in the context of clear market failure can be satisfied at a purely interpersonal level. It is impossible to engage in an imaginative reconstruction of the life situation of the person on the other side of the exchange relation if the product being exchanged leaves no trace of who that person is. Instead, Wilson suggested, individuals will 
orient their sympathetic capacities to the broader economic structure into which they are incorporated alongside other people. At this level, the people who stand to benefit from market-correcting welfare policies come vicariously back into view.

Once again we should note the potentially significant re-inflection of the concept of sympathy in evidence here. For Smith it meant a directly experienced moment of fellow-feeling between one person and another, whereas in Wilson's hands it appears to be much closer to the social process of legitimation. As the structure itself is an intangible aspect of people's economic experience, they are likely to direct their moral judgement - this time as assessments of legitimacy - towards the more tangible intermediary between themselves and the structure. This is the output of the state’s public policy-making apparatus. As Wilson argued (1976, 88), Smithian sympathy can today manifest itself in support for 'certain kinds of public policy', provided that they are of an ameliorative nature in the face of widening socioeconomic inequalities. The image is of a socialised sphere of Smithian sympathy corresponding roughly to instinctive approval of the post-war welfare state and its redistributive capacities.

The proviso is significant. It represents a means of re-personalising the process of sympathy so that it does not become completely indistinguishable from legitimation. Concerns for ameliorative interventions revolve around a well-tutored imagination suited to the task of exercising moral judgement. In such circumstances, a person does not need to directly observe the situations in which the poor routinely find themselves so as to develop an imprint of those situations in the mind. This can be achieved solely through psychic projection. As such, it is possible to visualise what it must be like, for instance, to lack the resources to meet current consumption needs in old age because of inadequate private insurance and therefore being forced to turn 
the heating down in winter to save on energy bills. A well-tutored imagination enables the individual to share in the experience of that situation vicariously in support of a properly funded state pension, even if he or she does not want for adequate private insurance and so will personally never have that experience directly. Insofar as that person is capable of exhibiting a relational self, other people's exposure to market failure in private insurance becomes an influence on his or her moral judgement.

The vicarious act of swapping places with someone else in the imagination helps to create a welfare state structure at odds with a purely autonomous self. It is always possible to call into the mind the image of a person who is poorer than you or more in need than you. When the mind is also inhabited by the promptings of the impartial spectator, it is also always possible to envision a reasonable justification for redistribution built on Smith’s system of practical ethics (Witzum, 1997; Verburg, 2000). The legitimation of the welfare state's redistributive capacities can therefore be, as Wilson argued, an act akin to sympathy. The post-war welfare state entered British political consciousness primarily as an abstraction offered in defence of government intervention (Pierson, 1994). As such, it was talked about in an impersonal manner, and it was often also experienced in the impersonal manner of receipt of monetary allowances. Nonetheless, its redistributive capacities did involve the transfer of resources from one person to another and, from there, they left the imprint of one person's social circumstances in the imagination of another person. They consequently also militated against the development of purely autonomous selves.

Merely the fact of being faced with a redistributive system of social insurance prompts those who are net contributors to query both its purpose and its rationale. In asking such a question, the relational self is immediately confronted by the ability of 
the imagination to summon up situations in which, say, a parent has to be told that they simply cannot afford the treatment which will cure their sick child. The question of whether it is legitimate to be asked to submit oneself to being a net contributor to social insurance schemes quickly becomes transposed into the question of whether it is legitimate to force other people into the situation of going without simply because they are poor. The process of moving between these two questions involves a similar process of shifting between constantly repeated images of self and other in making the moral judgement of where right lies. The relational self is at least partially constituted by the type of imaginative activities which merely living within a redistributive system of social insurance calls forth. From Wilson's perspective of socialised Smithian sympathy, the post-war welfare model in Britain therefore appears to come complete with its own in-built duty of care - at least in its ideal-typical form.

Brown's assertion that it is necessary for the British Government to 'do more for those born on the wrong side of the social arithmetic' (Brown, 2006b) appears to point in the same direction. The record of New Labour's first two terms in government is one of mild but nonetheless clear redistribution through active welfare policies to the in-work poor (Toynbee and Walker, 2005). At the same time, though, there has been an equally clear residualisation of recipient status in order to effect agential change at the heart of the welfare model. The final section explores whether these reforms safeguard Wilson's identification of the socialisation of a modified Smithian sympathy through the post-war welfare state.

\section{AN ASSET-BASED SYSTEM OF WELFARE AND THE SOCIALISATION OF SMITHIAN DUTY}


From its opening days in office until at least the onset of the credit crunch in 2007, New Labour trumpeted its ability to find much more money than any of its predecessors for financing key public services. The new money has been accompanied, however, by attempts to reconfigure people's core relationship with the public sector so as to foster further self-reliance for the future. These changes have been made manifest most obviously in efforts to remake the individual by challenging the rights traditionally associated with the post-war welfare state. New citizen subjectivities have been actively encouraged as a means of exposing more and more people to a brand of financialised capitalism with a view to integrating them within its structures (Langley, 2008).

Many people remain excluded from the trend due to a basic lack of access to resources. This means that the image of a fully realised asset-based system of welfare is still only an ideal-type. Yet, ever larger sections of the British middle classes have been incorporated into a welfare model founded on the principle of asset ownership rather than state provision (Cronin, 2004; Coates, 2005), so the trend is very definitely visible. The overall goal has been to facilitate individual acquisition of assets as a means of meeting future welfare needs beyond the sphere of state provision. The asset-rich individual can cash in accumulated wealth in later life to purchase welfareenhancing services in excess of those that the state can afford to make available (Sherraden, 2005). The redistributive fiscal policies which underpinned the post-war welfare state are prejudicial to the type of 'sound money' environment usually associated with asset price inflation. In order to create the financial space for asset accumulation, then, a trajectory of residualising welfare recipient status is required in order to make the welfare state more affordable. The beneficiary of existing welfare 
rights is thereby downgraded vis-à-vis the aspiring beneficiary of asset accumulation in terms of the claims that can be made against the public policy process.

One is immediately struck by the difficulties of trying to match the aspirant individual under the newer system to genuine Smithian sympathy. Under recent Treasury interventions, the realisation of one's potential is deeply encoded with economic meaning, rather than with processes that might lead to moral refinement. It is the potential to be a worker, requiring access to the labour market (Brown, 2002); it is the potential to be a saver, requiring access to a bank account (Balls, 2007); and it is the potential to be an investor, requiring access to advice about how to make money grow (HM Treasury, 2001a). Moreover, nurturing the individual's economic potential equates with removing state support for those who do not voluntarily take available opportunities to recast their identity as worker-saver-investors. The much-heralded ‘enabling government’ (Brown, 2000, 2003a, 268, 2005a) performs its role only for those who accept its demands for a particular type of agential self-awareness linked to the financialisation of everyday life. Alan Finlayson $(2008,98)$ describes New Labour's overall approach in this respect as one of "social democratic paternalism”, whereby it presents itself to the population on the basis of knowing better what is right for individuals than they do for themselves. This is more than likely to stretch Smith's notion of sympathy beyond breaking point, because he would only sanction its use to describe situations of agential self-actuation (Smith, 1982 [1759], I.i.3.1).

The paternalistic approach has an important impact on the content of the imaginative acts inferred by the move to a system of asset-based welfare. It is about being told what to do and following that advice accordingly, not learning what to do through the agential self-actuation of the relational self. In practice, then, New Labour's policies move people away from genuinely sympathetic relationships and 
resituate them in dutiful relationships. In Smith's terms, this can only be a second-best solution. Moreover, Brown's envisioned duty contains none of the essential features of Smith’s practical ethics, because it does not imply a relationship genuinely between people. Within the specific context of the Treasury's oversight of the shift towards a system of asset-based welfare, Brown's rhetoric of duty takes two forms: neither is of an interpersonal nature. One is a duty to oneself, whereas the other is a duty to the state.

(1) The Government has presented the role of the active worker-saver-investor in terms of a duty to oneself to manage lifetime income in order to increase selfsufficiency. It has signalled its intention to withdraw some of the state's activities designed to secure welfare in old age (HM Treasury, 2001b; Pensions Commission, 2005). Consequently, individuals stand to experience future welfare gaps in the absence of accumulated assets that will release income streams when cashed in. The Treasury has embarked on a concerted financial literacy drive, the aim of which has been to emphasise what people will miss out on in the future if they do nothing to adopt a savings habit in the present as a means of standing on one's own feet (HM Treasury, 2006).

Smith also argued that every person 'is first and principally recommended to his own care' (Smith, 1982 [1759], VI.ii.1.1) and that the single most important impetus for social progress is the desire for 'bettering one's condition' (Smith, 1981 [1776], II.iii.28, 1982 [1759], IV.1.8). However, he treated this simply as a necessary attribute of human existence, a natural element of the survivalist instinct (Force, 2003, 64-6). It is an essentially pre-social phenomenon, even if it then follows people into society. For Smith, duties have a completely different make-up (Evensky, 2005, 40- 
4). They are irreducibly social, reflecting in content the evolution of the prevailing social formation and making sense only in relation to the individual's location within society (Smith, 1982 [1759], III.1.3). Smith treated excessive attention to the self as the primary threat to the exercise of duty and therefore as a notable impediment to the ease of social living. He identified a tendency for people to sympathise too readily with the fortunate and to be too reticent in accepting fellow-feeling for the unfortunate (ibid, I.iii.3.1). The moral sentiments are consequently distorted by the strength of our desire to imagine ourselves surrounded by the possessions of the rich (Skinner, 1979, 58-9).

Yet, the Government's financial literacy drive highlights the advantages of being asset-rich and invites people to imagine themselves sharing the material benefits that follow from such a status (HM Treasury/Inland Revenue, 2003). As Finlayson (2008) has shown to great effect, the advertising campaign run by the Government when introducing the Child Trust Funds followed precisely this pattern. Under the strap-line 'What will yours grow into?' (www.childtrustfund.gov.uk), the objectives of modern parenting were recast to include passing on to children the knowledge of how to care for themselves financially by aspiring to richness. But by acting on this encouragement individuals stand to replicate precisely the behaviour that Smith associated with the corruption of the learned moral instinct for acting dutifully. The policies promoted by Brown's Treasury invoke the image of being responsible only for oneself, but from a Smithian perspective this would seem to be at the expense of understanding that to be properly dutiful means to perform duties to other people. 
(2) The Government has also presented the role of the active worker-saver-investor in terms of a duty to the state to reduce claims on the Treasury. The implications of the $£ 500$ billion bailout for the banks worst affected by the credit crunch (Independent, 9 October 2008) make it likely that additional vigilance will in the future be advocated on matters of fiscal and monetary stability. This will accentuate the process through which expectations of future state-sponsored welfare-enhancing expenditures have already been managed downwards. New Labour has championed individuals who act to secure their own welfare futures, because these people serve the public interest by providing the conditions for fiscal and monetary stability.

There is nothing to be found in Smith's reflections on the nature of duties - let alone that of sympathy - which comes close to resembling this latter of New Labour's two positions on the ethics of the active worker-saver-investor. As has been shown, for Smith, the instinct to act sympathetically is self-tutored through a process of externalising the self in imaginative form so that we can gain an understanding of how our intended conduct looks to other people. But it is clear that in Smith's mind we externalise ourselves in distinctively human form. Our imagination can only copy the sense of being that is encapsulated in our own experience of the world (Smith, 1982 [1759], I.i.1.2). As that experience consists of living life as one person amongst many, when we attempt the process of fellow-feeling the imprint that leaves our mind is necessarily in human form. It is the content of the act of imaginative projection, then, which defines sympathy as a fundamentally interpersonal phenomenon. Moreover, for those people who have yet to develop the instinct for sympathy, their imaginative projections define duty in exactly the same manner.

Either way, we cannot externalise ourselves, even in the imagination, in the form of a technical abstraction such as 'the state'. Living life as such an abstraction is 
simply not part of our experience of being, which ensures that the imagination has no means of replicating it in spectatorial form. For this reason, it is impossible to envisage having duties to the state from a Smithian perspective. In fact, whatever relationship of duty exists in this respect runs in the opposite direction. Smith called on state managers to emulate the 'man of prudence' (ibid, VI.i.1-16) by stopping themselves from using the power of the state to encroach on the process through which the individual arrives at moral judgement. New Labour's attempts to constitute active worker-saver-investors not only encroach on that process by removing them from the socialised sympathy of the post-war welfare state; they also seek to reshape their whole sense of being.

On the basis of the foregoing, I conclude that the effort that New Labour has put into changing basic economic subjectivities in Britain from passive welfare recipient to active worker-saver-investor is at least one step too far for the concept of socialised sympathy. The fact that it is dutiful behaviour embodied in the image of the new model welfare citizen takes us away from sympathy in any case. Furthermore, the structure of duties encompassed by such a shift is distinctly un-Smithian in its formulation. The adoption of active worker-saver-investor characteristics encourages a distinct partiality to the self in moral judgement when compared with the legitimation of the post-war British welfare state. Smith took such partiality to infer the deactivation of the impartial spectator. Active worker-saver-investor characteristics are therefore a distortion of the basic elements of sympathy rather than a contemporary example of socialised sympathy (ibid, III.4.4).

The important difference here is at the level of individual subjectivity. The development of a relational self is a prerequisite of expressions of sympathy. An 
individual who seeks immersion in a structure of sympathy must first have the imaginative capacity to switch repeatedly between mental images of self and other. The relegation of the self to one of two equal focal points in the mind makes partiality to the self much less likely. The fact that New Labour positively encourages such partiality in active worker-saver-investors suggests that it is attempting a wholesale remaking of the relational self who balances images of self and other in preparation for moral judgement. In its place an autonomous self is being advocated. Such a person is required to compute much less complex scenarios before arriving at moral judgement. The only mental image required for the autonomous self to act is that of his or her own needs.

The autonomous self is perfectly adapted for a world in which duty dominates all other forms of moral action. When duties are enshrined in law, autonomous selves develop into coherent moral agents simply by holding in mind the image of themselves interacting with the demands of legal statutes. If the law encourages respect for the type of redistributive policies reminiscent of the post-war welfare state, then duties can still be performed in an other-directed manner. The result of these sorts of duties is likely to be indistinguishable from the result of the socialised sympathy Wilson associated with the post-war welfare state. Both will be of an ameliorative nature and will therefore serve as a counterpoint to widening socioeconomic inequalities.

However, the crux of New Labour's attempts to embed an asset-based system of welfare is that no such ameliorative dimension is intended. There will be help for people to get back into work, help for them to begin saving and help for them to know how to invest their savings once they have accrued. But, after that, whatever assetbased wealth they build up will be theirs to keep: there will be no subsequent 
redistributive intervention by the Government. The socialised duty incorporated in the image of New Labour's ideal active worker-saver-investors is noticeably self-serving in its effects.

\section{CONCLUSION}

It remains a source of great interest - both scholarly and political - that Gordon Brown has attempted to reclaim Adam Smith for the British left. It is particularly significant that he has tried to push on from this in order to position an ostensibly modern left interpretation of Smith at the core of his philosophy for government (see McLean, 2006). My aim in this article has been rather modest by comparison. It has not been my intention to dismiss Brown's self-proclaimed Adam Smith connection out of hand. My conclusion is simply that the Treasury's attempted transformation of the subjectivities of welfare recipients fits poorly with Smith's concept of sympathy. The Department of Communities and Local Government's aspiration to engender individuals who perform voluntary community tasks might on some measures equate rather better with Smithian sympathy (DCLG, 2008). But it is the Treasury that has been instrumental in reconfiguring the British welfare model, not the DCLG, and this has been my focus.

The Treasury’s preferred economic agents - active worker-saver-investors have their sympathetic capacities curtailed by state demands that they are turned inwards to meet their own needs. What gets lost here are the multiple projections of self and other which for Smith worked together in an iterative process that produces the ability to exercise real fellow-feeling (Boltanski, 1999; Raphael, 2007). The attempt to align the legitimacy structure of the post-war welfare state with relational 
selves has given way to a new focus on encouraging the purely autonomous self. When the imaginative imprints of other people are removed from the process in this way, moral judgement becomes increasingly divorced from the impartiality that Smith had in mind as the condition of genuine sympathy. It is possible to view the post-war British welfare state as an institutional structure capable of socialising sympathy. But the changes to the model of welfare introduced by New Labour have removed that possibility by incentivising partiality to an autonomous self amongst net contributors to social insurance schemes. The tendential shift between these two welfare citizen ideal-types has implications not only for the way in which we understand the reform trajectory of New Labour, but also that of other welfare states in transition.

\section{NOTES}

1. This article was written with the assistance of a grant from the Economic and Social Research Council (number RES-000-22-2198, 'Rethinking the Adam Smith Problem'). I gratefully acknowledge the ESRC's continuing support of my research. I also thank the two anonymous referees who commented perceptively on the earlier version of the article.

\section{REFERENCES}

Balls, Ed (2007), 'The second Saving Gateway pilot', Speech delivered to the Bristol Institute of Public Affairs, University of Bristol, 25.05.07.

Boltanski, Luc (1999), Distant Suffering: Morality, Media and Politics, translated by Graham Burchell, Cambridge: Cambridge University Press. 
Braudel, Fernand (1982), The Wheels of Commerce: Civilization and Capitalism, $15^{\text {th }}$ $18^{\text {th }}$ Century, Volume II, translated by Siân Reynolds, London: Collins.

Brown, Gordon (2000), 'Civic society in modern Britain', The $17^{\text {th }}$ Arnold Goodman Lecture, Merchant Taylor's Hall, London, 20.07.00.

Brown, Gordon (2002), 'The strength to make long-term decisions: Investing in an enterprising, fairer Britain', Budget Report, Speech delivered to the House of Commons, 17.04.02.

Brown, Gordon (2003a), 'State and market: Towards a public interest test', Political Quarterly, 74: 3, 266-284.

Brown, Gordon (2003b), Speech delivered to the Social Market Foundation, Cass Business School, London, 03.02.03.

Brown, Gordon (2005a), Speech delivered to the Volunteering Conference, H.M. Treasury, London, 31.01.05.

Brown, Gordon (2005b), 'Politics as a moral duty', Speech delivered to the Labour Party Conference, Brighton, 26.09.05.

Brown, Gordon (2005c), 'The Hugo Young memorial lecture', Speech delivered at Chatham House, 13.12.05.

Brown, Gordon (2006a), Speech delivered to the Lord Mayor's Banquet, Mansion House, London, 21.06.06.

Brown, Gordon (2006b), 'The Donald Dewar memorial lecture', Speech delivered at the University of Glasgow, 12.10.06.

Brown, Gordon (2007), Speech delivered to the Labour Party Conference, Bournemouth, 24.09.07.

Coates, David (2005), Prolonged Labour: The Slow Birth of New Labour Britain, Basingstoke: Palgrave Macmillan. 
Cronin, James (2004), New Labour's Pasts: The Labour Party and Its Discontents, Harlow: Pearson.

DCLG (2008) Communities in Control: Real People, Real Power, London: Department of Communities and Local Government.

Esping-Andersen, Gøsta (1990), The Three Worlds of Welfare Capitalism, Cambridge: Polity Press.

Evensky, Jerry (2005), Adam Smith's Moral Philosophy: A Historical and Contemporary Perspective on Markets, Law, Ethics, and Culture, Cambridge: Cambridge University Press.

Finlayson, Alan (2008), 'Characterizing New Labour: The Case of the Child Trust Fund’, Public Administration, 86: 1, 95-110.

Force, Pierre (2003), Self-Interest before Adam Smith: A Genealogy of Economic Science, Cambridge: Cambridge University Press.

Griswold, Charles (1999), Adam Smith and the Virtues of Enlightenment, Cambridge: Cambridge University Press.

HM Treasury (2001a), Saving and Assets For All: The Modernisation of Britain's Tax and Benefit System, Number Eight, London: HM Treasury.

HM Treasury (2001b), Myners Review of Institutional Investment in the UK: Final Report, London: HMSO.

HM Treasury (2006), Pre-Budget Report 2006, London: HM Treasury.

HM Treasury/Inland Revenue (2003), Detailed Proposals for the Child Trust Fund, London: HMSO.

Langley, Paul (2008), The Everyday Life of Global Finance: Sa ving and Borrowing in Anglo-America, Oxford: Oxford University Press. 
Lee, Simon (2007), Best for Britain? The Politics and Legacy of Gordon Brown, Oxford: Oneworld.

McLean, Iain (2006), Adam Smith, Radical and Egalitarian: An Interpretation for the $21^{\text {st }}$ Century, Edinburgh: Edinburgh University Press.

Montes, Leonidas (2004), Adam Smith in Context: A Critical Reassessment of some Central Components of His Thought, Basingstoke: Palgrave Macmillan.

Pensions Commission (2005), A New Pension Settlement for the Twenty-First Century: The Second Report of the Pensions Commission, London: HMSO.

Pierson, Paul (1994), Dismantling the Welfare State? Reagan, Thatcher, and the Politics of Retrenchment, Cambridge: Cambridge University Press.

Raphael, David Daiches (2007), The Impartial Spectator: Adam Smith's Moral Philosophy, Oxford: Oxford University Press.

Sherraden, Michael (2005), ‘Assets and Public Policy’, in idem (ed.), Inclusion in the American Dream: Assets, Poverty, and Public Policy, Oxford: Oxford University Press, pp. 3-19.

Skinner, Andrew (1979), A System of Social Science: Papers Relating to Adam Smith, Oxford: Clarendon Press.

Slater, Don and Tonkiss, Fran (2001), Market Society: Markets and Modern Social Theory, Cambridge: Polity.

Smith, Adam (1981 [1776]), An Inquiry into the Nature and Causes of the Wealth of Nations, Indianapolis, IN: Liberty Fund.

Smith, Adam (1982 [1759]), The Theory of Moral Sentiments, Indianapolis, IN: Liberty Fund.

Smith, Adam (1982), Lectures on Jurisprudence, Indianapolis, IN: Liberty Fund. 
Toynbee, Polly and Walker, David (2005), Better or Worse? Has Labour Delivered?, paperback edition, London: Bloomsbury Publishing.

Verburg, Rudi (2000), ‘Adam Smith’s Growing Concern on the Issue of Distributive Justice', European Journal of the History of Economic Thought, 7: 1, 23-44.

Weinstein, Jack Russell (2006), 'Sympathy, Difference, and Education: Social Unity in the Work of Adam Smith', Economics and Philosophy, 22: 1, 1-33.

Wilson, Thomas (1976) 'Sympathy and Self-Interest', in Thomas Wilson and Andrew Skinner (eds.), The Market and the State: Essays in Honour of Adam Smith, Oxford: Clarendon Press, pp. 73-99.

Witzum, Amos (1997), 'Distributive Considerations in Smith's Conception of Economic Justice', Economics and Philosophy, 12: 2, 241-259. 